\title{
Effects of the buriti (Mauritia flexuosa L.) oil supplementation on crossbred lactating goats: behavioral, physiological, and hematological responses
}

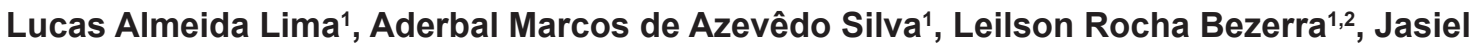 \\ Santos de Morais ${ }^{1}$, Marcos Jácome de Araújo², Ronaldo Lopes Oliveira ${ }^{3}$, Tairon Pannunzio \\ Dias e Silva ${ }^{4}$, Elzânia Sales Pereira ${ }^{5}$
}

\footnotetext{
${ }^{1}$ Universidade Federal de Campina Grande, Departamento de Zootecnia, Patos, PB, Brazil.

${ }^{2}$ Universidade Federal do Piauí, Departamento de Zootecnia, Bom Jesus, PI, Brazil.

${ }^{3}$ Universidade Federal da Bahia, Departamento de Zootecnia, Salvador, BA, Brazil.

${ }^{4}$ Universidade de São Paulo, Centro de Energia Nuclear na Agricultura, Piracicaba, SP, Brazil.

${ }^{5}$ Universidade Federal do Ceará, Departamento de Zotoecnia, Fortaleza, CE, Brazil.
}

\begin{abstract}
This study aimed to evaluate the buriti oil (Mauritia flexuosa L.) inclusion levels (0, 15, 30, and $45 \mathrm{~g} \mathrm{~kg}^{-1}$ in dry matter) replacing ground corn on the feeding behavior, as well as physiological and hematological variables of crossbred lactating Anglo Nubian goats. Eight Anglo Nubian goats were used, which were distributed in a double $4 \times 4$ Latin square experimental design (four periods and four levels of buriti oil) replacing corn in the total dry matter. For the evaluation of feeding behavior, single animals were observed every ten minutes for $24 \mathrm{~h}$ on three days. Respiratory rate (RR), heart rate (HR), rectal temperature $(\mathrm{RT})$, and sweating rate $(\mathrm{SR})$ of the animals were evaluated in the morning $(09: 00 \mathrm{~h})$ and in the afternoon $(15: 00 \mathrm{~h})$. Blood samples were always taken in the morning, before feeding, by puncturing the jugular vein for the complete blood count and white blood cell count. The levels of buriti oil had no effect on feeding, rumination, idling time, water intake, defecation and urination, DM intake, feed efficiency, and rumination efficiency of DM and NDF, but had effects on NDF intake. Physiological variables (RT, SR, RR, and HR) in both periods of the day were not influenced by the inclusion of buriti oil. However, SR and RR were higher in the afternoon than in the morning. In erythrocyte, results showed that the hematocrit and mean corpuscular volume increased with the inclusion of buriti oil. Hemoglobin, red blood cell count, mean corpuscular hemoglobin concentration, and total plasma protein were not affected by the inclusion of buriti in the goat diet. The inclusion of buriti oil is recommended in up to $45 \mathrm{~g} \mathrm{~kg}^{-1}$ (DM basis) as a replacement for ground corn in diet of lactating goats without affecting the feeding behavior and physiological and hematological variables.
\end{abstract}

Key Words: adaptive capability, feeding behavior, goat, lipid source

\section{Introduction}

Vegetable oil is considered as a source of unsaturated fats in diets for ruminants. Therefore, it can influence the microbial metabolism in the rumen and, consequently, the feeding behavior of ruminants (Lima et al., 2015). Hence, supplementation of vegetable oils in ruminant diets must not exceed $70 \mathrm{~g} \mathrm{~kg}^{-1}$ of total DM. Inclusion of more than $70 \mathrm{~g} \mathrm{~kg}^{-1}$ of oil can interfere in ruminal fermentation and, therefore, lead to a reduction in the digestibility of nutrients, especially fiber (Lima et al., 2015). In contrast, energy supplements with the base oils can reduce the feed costs, but

Received: February 25, 2017

Accepted: September 18, 2017

*Corresponding author: tairon.mvet@gmail.com

Copyright (c) 2018 Sociedade Brasileira de Zootecnia. This is an Open Access article distributed under the terms of the Creative Commons Attribution License (http://creativecommons.org/licenses/by/4.0/), which permits unrestricted use, distribution, and reproduction in any medium, provided the original work is properly cited. it is essential to maintain the balance of energy and protein in the rumen (Costa et al., 2016). Balanced diets can promote an increase in feed efficiency and milk production.

Thus, the use of vegetable oils in the feed of ruminant animals has been used aiming to promote increased energy density of diets offered to animals and, thus, result in increased efficiency of production of meat and milk due to the high calorie content level (Gonzaga Neto et al., 2015; Oliveira et al. 2015a). In addition, the search for new alternative diets that will meet the nutritional requirements of animals without increasing the heat produced by ruminal fermentation drew interest from some researchers by the use of lipids in ruminant feed. Furthermore, the use of oil increases the energy density in the diet without the risk of nutritional disorders (Silva et al., 2016a).

Buriti (Mauritia flexuosa L.) is a palm tree that occupies paths where the soil is soaked. It plays a key role in maintaining springs and waterways, being essential to the ecosystem. The buriti culture is traditional due to 
the high versatility of this palm tree, which has all of its components used (leaves, fruit, and oil) (Sousa et al., 2012) as a source of income for farmers and agribusinesses. The oil extracted from the buriti fruit is of great interest due to the physical and chemical properties that present a high concentration of tocopherols and carotenoids (França et al., 1999; Durães et al., 2006). Thus, the oil extracted from the pulp or peel of buriti can be used as an energy source in the diet of lactating goats. However, to provide an alternative source of feed, such as buriti oil, it is necessary to understand the behavior patterns and intake of animals (Silva et al., 2015a; Silva et al., 2015b; Silva et al., 2016b), as well as the possible changes that can occur in the physiological and biochemical variables (Mendes et al., 2015). To include alternative lipid sources in diets for crossbred animals, considered heat-tolerant, the climatic variables should be considered (Nardone et al., 2010). In this context, to improve nutritional management practices it is necessary to determine the best level of vegetable oil in the ruminant diet to increase productive capacity and production system.

Therefore, the use of buriti oil can be important to increase the energy density of goat diet replacing ground corn without negative effects on feeding behavior, physiological parameters, and hematological variables. In addition, buriti oil can reduce the heat increment from feed fermentation (Silva et al., 2015a) promoting a better adaptive capability of goats to a hot environment and, consequently, improve milk and meat production. Thus, this present study aimed to evaluate buriti oil replacing ground corn on the feeding behavior, as well as the physiological and hematological parameters of crossbred lactating goats.

\section{Material and Methods}

The experiment was carried out in Bom Jesus, Piauí, Brazil, which is located in the $09^{\circ} 04^{\prime} 28^{\prime \prime}$ South latitude and $44^{\circ} 21^{\prime} 31^{\prime \prime}$ West longitude. Research on animals was conducted according to the institutional committee on animal use (case no. 205-2014).

Eight multiparous lactating Anglo Nubian goats with an average of $50 \pm 4$ days of lactation and of $38.4 \pm 1.1 \mathrm{~kg}$ weight were used; the animals were housed in individual $3.9-\mathrm{m}^{2}$ stalls with wooden floors and were provided with feed and water. The animals were randomly distributed in double Latin square $(4 \times 4)$ composed of four periods and four buriti oil levels $\left(0,15,30\right.$, and $\left.45 \mathrm{~g} \mathrm{~kg}^{-1}\right)$ replacing ground corn in the total DM (Table 1). The experimental study was conducted for 80 days divided into four periods of
20 days, with the first 15 days of each period for adaptation to the experimental diets and the next five days for data collection.

The diets were formulated according to NRC (2007) recommendations to meet the nutritional requirements of lactating goats with production of $1.5 \mathrm{~kg}$ milk/goat/day, corrected for $4 \%$ fat. The diet consisted of corn silage as roughage and a concentrate composed of meal-based soybean, livestock urea, calcitic calcarium, mineral mixture, and buriti oil at increasing levels $\left(0,15,30\right.$, and $45 \mathrm{~g} \mathrm{~kg}^{-1}$ $\mathrm{DM}$ basis) replacing ground corn, using forage:concentrate ratio of 50:50. The feed offered and feed refusals were weighted daily. The amount of feed was adjusted daily to achieve between 10 and 20\% leftovers to ensure ad libitum intake conditions. Water was provided ad libitum and intake quantified daily during the collection period. The diets were offered twice a day at 08:00 and 17:30 h, after milking.

The intake of DM and NDF was calculated in the five days of collection as the difference between the total DM and NDF contained in the feed offered and the total DM and NDF contained in the feed refusals. Samples of feed, feed refusals, and feces were collected in the last five days of each trial period for posterior analyses. These samples were placed in plastic bags (Electro Plastic ${ }^{\circledR}$, São Paulo, Brazil) with proper identification of the treatments, animals, and collection period and stored in a freezer at $-20^{\circ} \mathrm{C}$ (Consul $\mathrm{CHB} 3 \mathrm{C}^{\circledR}$, Teresina, Piauí, Brazil). At the end of each experimental period, the samples (of ingredients, diets, and refusals) were thawed, homogenized, and a composite sample (250 grams) withdrawn from each treatment, animals, and period. The samples were pre-dried in an oven (in triplicate) with forced ventilation at $55^{\circ} \mathrm{C}$ for $72 \mathrm{~h}$ and ground in a mill Willey (Tecnal, Piracicaba City, São Paulo State, Brazil) at a $1-\mathrm{mm}$ mesh sieve, and feces at a $2-\mathrm{mm}$ sieve, and analyzed (in triplicate) to determine dry matter (DM) (method 967.03), ash (method 942.05), crude protein (CP) (method 981.10), and ether extract (EE) (method 920.29) according to the Association of Official Analytical Chemists (AOAC, 1990). To determine the neutral detergent fiber (NDF) and acid detergent fiber (ADF) contents, the methodology of Van Soest et al. (1991) was used with the modifications proposed in the Ankon device manual (Ankon Technology Corporation, Macedon, New York, US).

Acid detergent lignin content was assessed according to the method 973.18 (AOAC, 2002), in which the ADF residue was treated with sulfuric acid $(72 \%)$. Neutral detergent fiber residue was incinerated in an oven at $600{ }^{\circ} \mathrm{C}$ for $4 \mathrm{~h}$ and the correction for protein content was applied by subtracting the neutral detergent insoluble nitrogen content 
(NDIN). The non-fiber carbohydrate (NFC) content of the ingredients was determined according to the methods of Mertens (1997) and calculated based on the differences in the equation: $(\mathrm{NFC}=100-\mathrm{NDF}-\mathrm{CP}-\mathrm{EE}-$ ash). This value was considered in the calculation of the NDF value corrected for ash and protein content. The neutral detergent insoluble nitrogen and acid detergent insoluble nitrogen values were obtained according to the recommendations of Licitra et al. (1996) (Table 1).

Individual observations of the animals were performed on days 17 and 19 for $24 \mathrm{~h}$ every ten-minute intervals to evaluate the feeding behavior (feeding, rumination, and idling), according to the method of Johnson and Combs (1991). The ingestive behaviors were considered mutually exclusive because, for each record, each animal was classified into only one activity (Carvalho et al., 2004). The data for each animal behavioral activities were recorded by two trained observers, who were positioned to interfere as little as possible with animal behavior. The observers took turns every $3 \mathrm{~h}$ and nighttime observations were conducted using artificial lighting. Also, the number of times that the animal defecated, urinated, and ingested water was also continuously monitored. Water intake was recorded as the number of times the animal spent looking for the fountain and ingesting water.

For the estimation of ruminating chews, three ruminal times in three different periods of the day (10-12, 14-16, and 18-20 hours) (Bürger et al., 2000) were evaluated, assessing the number of ruminating chews and the time spent in rumination of each ruminated bolus (sec/bolus), using a digital chronometer (Johnson and Combs, 1991). This mastication was calculated through three periods of $15 \mathrm{~s}$ by multiplying the average by 4 to obtain the chewing time per minute (chew/min).

The feeding efficiency (FE), rumination efficiency (RE), and total chewing time (h/day), as the sum of the time eating and ruminating (FT $+\mathrm{RT}$ ), were determined according to Bürger et al. (2000). The results for the feeding behavior parameters were obtained using the following equations:

$$
\begin{gathered}
\mathrm{NRB}=\mathrm{RT} / \mathrm{NC} ; \\
\mathrm{NC}=\mathrm{NRB} \times \mathrm{NC} ; \\
\mathrm{FEDM}=\mathrm{DMI} / \mathrm{FT} ; \mathrm{FENDF}=\mathrm{NDFI} / \mathrm{FT} ; \\
\text { REDM }=\text { DMI } / \mathrm{RT} ; \mathrm{RENDF}=\mathrm{NDFI} / \mathrm{RT} ; \text { and } \\
\text { TCT }=\text { FT }+ \text { RT },
\end{gathered}
$$

in which $\mathrm{NRB}=$ number of ruminal boli; $\mathrm{NC}=$ daily number of chews; FEDM = feed efficiency of DM ( $\mathrm{g}$ DM consumed/h); FENDF $=$ feed efficiency of NDF $(g$ NDF consumed/h); DMI (g) = daily dry matter intake; NDFI $(\mathrm{g})=$ daily neutral detergent fiber intake; FT = time spent feeding daily; REDM = rumination efficiency of DM ( $g$ of ruminated $\mathrm{DM} / \mathrm{h}) ; \mathrm{RENDF}=$ rumination efficiency of NDF (ruminated NDF/h); RT (h/day) = rumination time; and $\mathrm{TCT}=$ total chewing time (h/day).

For each animal, three measurements were obtained (three days of feeding behavior analysis) for each parameter. Based on these three measurements, the mean of each

\begin{tabular}{|c|c|c|c|c|}
\hline & \multicolumn{4}{|c|}{ Buriti oil inclusion $\left(\mathrm{g} \mathrm{kg}^{-1} \mathrm{DM}\right)$} \\
\hline & 0 & 15 & 30 & 45 \\
\hline \multicolumn{5}{|l|}{ Proportion of ingredients $\left(\mathrm{g} \mathrm{kg}^{-1} \mathrm{DM}\right)$} \\
\hline Corn silage & 500 & 500 & 500 & 500 \\
\hline Soybean meal & 105.0 & 104.4 & 103.8 & 103.2 \\
\hline Ground corn & 365 & 350 & 335 & 320 \\
\hline Buriti oil & - & 15.0 & 30.0 & 45.0 \\
\hline Urea & - & 0.60 & 1.20 & 1.80 \\
\hline \multicolumn{5}{|l|}{ Chemical composition } \\
\hline Dry matter (as fed) & 570 & 571 & 573 & 574 \\
\hline Ash $\left(\mathrm{g} \mathrm{kg}^{-1} \mathrm{DM}\right)$ & 48 & 48 & 47 & 47 \\
\hline Crud protein $\left(\mathrm{g} \mathrm{kg}^{-1} \mathrm{DM}\right)$ & 120 & 120 & 121 & 121 \\
\hline Ether extract $\left(\mathrm{g} \mathrm{kg}^{-1} \mathrm{DM}\right)$ & 34 & 48 & 62 & 75 \\
\hline Neutral detergent fiber $\left(\mathrm{NDF}_{\mathrm{ap}}\right)\left(\mathrm{g} \mathrm{kg}^{-1} \mathrm{DM}\right)$ & 310 & 308 & 306 & 304 \\
\hline
\end{tabular}
parameter was calculated for each animal for statistical analysis.

Table 1 - Proportions and chemical compositions of experimental diets containing buriti oil (Mauritia flexuosa L.) replacing ground corn to lactating goats

$\mathrm{DM}$ - dry matter; $\mathrm{CP}$ - crude protein; $\mathrm{NDF}_{\text {ap }}$ - neutral detergent fiber corrected for ash and protein.

${ }^{1}$ Safe levels: calcium, $120 \mathrm{~g} \mathrm{~kg}^{-1}$; phosphorus, $30 \mathrm{~g} \mathrm{~kg}^{-1}$; chlorine, $198 \mathrm{~g} \mathrm{~kg}^{-1}$; sodium $129 \mathrm{~g} \mathrm{~kg}^{-1}$; sulfur, $17 \mathrm{~g} \mathrm{~kg}^{-1}$; magnesium, $2,500 \mathrm{mg} \mathrm{kg}$; ;ron, $1,000 \mathrm{mg} \mathrm{kg}{ }^{-1}$; manganese, $1,000 \mathrm{mg} \mathrm{kg}^{-1}$; copper, $150 \mathrm{mg} \mathrm{kg}$; iodine, $150 \mathrm{mg} \mathrm{kg}^{-1}$; cobalt, $35 \mathrm{mg} \mathrm{kg}$; ; selenium, $15 \mathrm{mg} \mathrm{kg}^{-1}$; fluorine, $300 \mathrm{mg} \mathrm{kg}^{-1}$. 
Readings of the environmental variables were performed at 09:00 and 15:00 $\mathrm{h}$, during the experimental period (five days $\times$ four periods) (Table 2). Hygrometer and thermometers (black globe, dry bulb, and wet bulb thermometers) were installed at the height of the animals. Those were used to monitor the experimental environment and measure and record the room temperature $\left(\mathrm{T}_{\mathrm{db}}\right)$, relative humidity $(\mathrm{RH})$, black globe temperature $\left(\mathrm{T}_{\mathrm{bg}}\right)$, and dew point temperature $\left(\mathrm{T}_{\mathrm{dp}}\right)$. To determine black globe temperature and humidity index, the following equation was used, according to Buffington et al. (1981): (BGHI = $\left.\mathrm{T}_{\mathrm{bg}}+0.36 \times\left(\mathrm{T}_{\mathrm{dp}}\right)+41.5\right)$. The temperature-humidity index (THI) was calculated using the equation $\mathrm{THI}=\mathrm{Tdb}+0.36$ Tdp +41.2 , as recommended by Yousef (1985).

The physiological responses of the animals were evaluated at 09:00 and 15:00 h, during the experimental period. That yielded five days $\times$ four experimental periods $x$ two-day period for each goat, in which the following parameters were measured: heart rate (HR), rectal temperature (RT), respiratory rate (RR), and sweating rate (SR). Respiration rate was measured in breaths per minute through direct observation of the movements of the left flank. Heart rate was determined using a stethoscope placed directly on the left thoracic region to count the number of beats over $20 \mathrm{~s}$ and the resultant value was multiplied by 3 to determine the number of beats per minute (beats $/ \mathrm{min}$ ). The insertion of a veterinary clinical thermometer (G-tech model TH150) into the rectum of the animal for $2 \mathrm{~min}$ was used to measure RT, with the temperature being read in Celsius. The clinical thermometer has a rated operating range of 10 to $43.9{ }^{\circ} \mathrm{C}$ with an accuracy of $0.2{ }^{\circ} \mathrm{C}$ and a measurement time of approximately $10 \mathrm{~s}$. Sweating rate was determined according to the method developed by Berman (1957) and modified by Schleger and Turner (1965): Whatman no. 1 filter paper sheets were soaked in a cobalt chloride $10 \%$ solution and dried in an oven at $40{ }^{\circ} \mathrm{C}$ for $2 \mathrm{~h}$. The dried paper was cut into small discs $(0.53 \mathrm{~cm}$ in diameter), which were, after further drying at $40{ }^{\circ} \mathrm{C}$ for 30 min, quickly placed on a microscope glass slide, three in number, and fixed with transparent-type adhesive tape. Mounted slides were stored in a desiccator containing silica gel. Trichotomy was performed in an area of $50 \mathrm{~cm}^{2}(5 \times 10 \mathrm{~cm})$ from the side

Table 2 - Mean of the variation in climatological data recorded during morning and afternoon experimental periods

\begin{tabular}{lcc}
\hline Environment variable & Morning & Afternoon \\
\hline Ambient temperature $\left({ }^{\circ} \mathrm{C}\right)$ & 28.2 & 32.7 \\
Relative humidity $(\%)$ & 59.2 & 47.3 \\
Temperature-humidity index & 76.6 & 82.8 \\
Black globe-temperature humidity index & 76.9 & 81.3 \\
\hline
\end{tabular}

of the region of each goat. The tape removed from the glass slide was applied onto the trichotomized area. The color change time (purplish blue to light pink) of the three discs was used to calculate the average. Turning to the average time, in seconds, the formula was applied:

$$
\mathrm{SR}\left(\mathrm{g} / \mathrm{min} / \mathrm{m}^{2}\right)=(22 \times 60) / 2.06 \times \mathrm{t},
$$

in which 22 is the number of grams of water required to change the color of $1 \mathrm{~m}^{2}$ of filter paper; 60 is the number of seconds per minute; the skin area covered by a disc is 2.06 times its area; and $t$ is the average time of change (in minutes).

Blood samples of goats were always collected by jugular venipuncture in the morning before the animals were fed at 16, 18, and 20 days of the collection period. Disposable needles $(25 \times 8 \mathrm{~mm})$ and glass vacutainer tubes containing $0.05 \mathrm{ml}$ of a $10 \%$ aqueous solution of ethylene diamine tetra acetic acid (EDTA) per $5 \mathrm{ml}$ of blood were used. The blood samples were kept in a cooler with ice (temperature between 2 and $8{ }^{\circ} \mathrm{C}$ ) until they were transported to the laboratory, and the hemogram was performed within $24 \mathrm{~h}$ (Bezerra et al., 2008). The hemogram consisted of the following measurements: global erythrocyte counts, packed cell volume, hemoglobin, absolute blood indices (mean corpuscular volume $[\mathrm{MCV}]$ and mean corpuscular hemoglobin concentration $[\mathrm{MCHC}])$, and total and differential leukocyte counts. The erythrocyte counts were performed using a modified Neubauer chamber and Gower's solution as a diluent. The packed cell volume was determined with the microhematocrit technique, using homogeneous capillary tubes of $75 \mathrm{~mm}$ in length and $1 \mathrm{~mm}$ in diameter.

The assessment of the hemoglobin content in the blood was done by the cyan methemoglobin method, using Drabkin's solution for the dilutions. The figures obtained by counting the red blood cells and by determining the packed cell volume and hemoglobin content were used to establish the absolute values of $\mathrm{RBC}$ indices prior to obtaining specific leukocyte counts. Total leukocyte counts were performed in a modified Neubauer chamber and blood samples were diluted as 1:20 in Turk's solution, according to the recommendations of Bezerra et al. (2008). Two smears of whole blood were used for the differential leukocyte counts. After drying, the smears were stained using a quick Romanowsky-type dye (Panoptic rapid LTDA Labor Clin ${ }^{\circledR}$, Pinewoods, Paraná, Brazil). Using a microscope at 1,000X magnification, 100 leukocytes were classified in each blood smear according to morphology and staining patterns. The leukocytes were classified as neutrophils, eosinophils, basophils, lymphocytes, or monocytes. The determination of total plasma protein 
(TPP) was performed by refractometry after the blood was centrifuged in microhematocrit capillary tubes.

The replicated Latin square design was used with four levels of buriti oil $\left(0,15,30\right.$, and $\left.45 \mathrm{~g} \mathrm{~kg}^{-1}\right)$, four periods, and four animals. All data were analyzed using the MIXED procedure of SAS (Statistical Analysis System, version 9.0). For ingestive behavior and hematology data, the oil level, period, and the oil level $\times$ period interaction were included in the model as fixed effects and the animal was considered as random effect. As for the physiological data, the fixed effects of environmental periods (morning and afternoon) and their interaction with the oil level were added to the model.

As the periods were equally spaced apart, the covariance structure for the residues was a first-order autoregressive (AR(1)) according to Tempelman (2004). When the interactions were significant, the $F$ test was conducted using the SLICE option of LSMEANS. In the presence of significant effect of oil level in a given period or environmental periods, the means of the treatments were compared using Dunnett's test $(\mathrm{P}<0.05)$. The residuals were plotted against the predicted values and were used to verify the homoscedasticity model assumptions, errors' independence, and normality. Data were considered outliers and removed from the database if the studied residue was outside the range of \pm 2.5 . The following model was used:

$$
Y_{i j k}=\mu+\alpha_{i}+\beta_{j}+c_{k}+\alpha \beta_{i j}+e_{i j k}
$$

in which $Y_{i j k}$ represents the observation on animal $k$ given treatment $i$ at period $j ; \alpha_{i}$ represents the fixed effect of the $i$-th treatment, $i=\left(0,15,30\right.$, and $\left.45 \mathrm{~g} \mathrm{~kg}^{-1}\right) ; \beta_{j}$ represents the fixed effect of the $j$-th period (1...4); $\alpha \beta_{i j}$ represents fixed effect of the interaction between the $i$-th treatment and $j$-th period; $c_{k}$ represents the random effect of the $k$-th animal (1...4); and $e_{i j k}$ is the experimental residue.

\section{Results}

There was no difference between the buriti oil levels tested in relation to the time the goats spent on feeding $(\mathrm{P}>0.05)$, rumination $(\mathrm{P}>0.05)$, and idling $(\mathrm{P}>0.05)$. Most of the time was spent in idling (average of $16.5 \mathrm{~h}$ ), followed by rumination (average of $4.4 \mathrm{~h}$ ), and the goats spent little time in feeding (average of $3.1 \mathrm{~h}$ ). The number of activities (/day) as defecation $(\mathrm{P}>0.05)$, urination $(\mathrm{P}>0.05)$, and water intake $(\mathrm{P}>0.05)$ was not affected by the inclusion of buriti oil in the diet of lactating goats.

The replacement of ground corn for buriti oil at the levels studied did not affect the DM $(\mathrm{P}>0.05)$ intake, but affected the NDF intake $(\mathrm{P}<0.05)$ of the goats (Table 3$)$. The feeding efficiency of DM $(\mathrm{P}>0.05), \mathrm{NDF}(\mathrm{P}>0.05)$, and rumination efficiency of DM $(\mathrm{P}>0.05)$ and NDF $(\mathrm{P}>0.05)$ were not affected.

The number of boli chewed/day ( $\mathrm{P}>0.05)$ was not affected by the levels of buriti oil tested in the diet (Table 3). In the same sense, there was no effect in total chewing (sec/bolus) $(\mathrm{P}>0.05)$, in the mean number of chews/bolus $(\mathrm{P}>0.05)$, and in the intake $(\mathrm{g} / \mathrm{DM} /$ bolus $)(\mathrm{P}>0.05)$ with the inclusion of buriti oil in the diet of goats.

The inclusion of buriti oil did not have a significant influence on the physiological variables (RT, SR, RR, and HR) in both periods of the day (Table 4). However, there was an increase in the SR and RR in the afternoon in relation to the morning.

Table 3 - Ingestive behavior of lactating goats fed diets with buriti oil replacing ground corn

\begin{tabular}{lccccc}
\hline \multirow{2}{*}{ Variable } & \multicolumn{3}{c}{ Buriti oil level $\left(\mathrm{g} \mathrm{kg}^{-1} \mathrm{DM}\right)$} & \\
\cline { 2 - 5 } & 0 & 15 & 30 & 45 & \\
\hline Feeding (h/day) & 2.74 & 3.37 & 3.07 & 3.23 & 0.3030 \\
Rumination (h/day) & $4.08 \mathrm{~b}$ & $4.19 \mathrm{~b}$ & $4.39 \mathrm{~b}$ & $5.10 \mathrm{a}$ & 0.1705 \\
Idling (h/day) & 17.3 & 16.6 & 16.5 & 15.8 & 0.0812 \\
Water ingesting (n/day) & 2.79 & 3.18 & 2.42 & 2.85 & 0.8310 \\
Defecating (n/day) & 3.09 & 3.45 & 5.25 & 4.07 & 0.0976 \\
Urinating (n/day) & 7.00 & 6.00 & 5.36 & 5.12 & 0.5492 \\
Intake (g/day) & & & & & \\
$\quad$ Dry matter & 1682 & 1701 & 1627 & 1630 & 0.2209 \\
$\quad$ Neutral detergent fiber & $581 \mathrm{a}$ & $551 \mathrm{a}$ & $528 \mathrm{~b}$ & $517 \mathrm{~b}$ & 0.0083 \\
Feeding eficiency (g/h) & & & & & \\
$\quad$ Dry matter & 618 & 507 & 520 & 508 & 0.8383 \\
$\quad$ Neutral detergent fiber & 213 & 165 & 120 & 101 & 0.3107 \\
Rumination eficiency (g/h) & & & & & \\
$\quad$ Dry matter & 423 & 507 & 520 & 508 & 0.1199 \\
$\quad$ Neutral detergent fiber & 146 & 130 & 120 & 101 & 0.1199 \\
Chewing & & & & & \\
$\quad$ Number boli (n/day) & 351 & 278 & 271 & 366 & 0.4685 \\
$\quad$ Time spent (sec/bolus) & 36.0 & 44.1 & 46.5 & 41.5 & 0.4670 \\
$\quad$ Number of chews (/bolus) & 47.2 & 84.0 & 85.6 & 60.5 & 0.1439 \\
$\quad$ Chewing (g/DM/bolus) & 6.17 & 8.93 & 8.56 & 5.22 & 0.6050 \\
\hline
\end{tabular}

DM - dry matter.

Means followed by different letters differ statistically $(\mathrm{P}<0.05)$ from the same variables in different buriti oil level by the Dunnett's test.

Table 4 - Physiological parameters of lactating goats fed diets with buriti oil replacing ground corn during the morning and afternoon

\begin{tabular}{|c|c|c|c|c|c|}
\hline \multirow{2}{*}{$\begin{array}{l}\text { Physiological } \\
\text { parameter }\end{array}$} & \multicolumn{4}{|c|}{ Buriti oil level ( $\left.\mathrm{g} \mathrm{kg}^{-1} \mathrm{DM}\right)$} & \multirow{2}{*}{ Mean } \\
\hline & 0 & 15 & 30 & 45 & \\
\hline \multicolumn{6}{|c|}{ Morning } \\
\hline Rectal temperature & 38.4 & 38.4 & 38.4 & 38.5 & $38.4 \mathrm{a}$ \\
\hline Sweating rate & 88.4 & 103 & 117 & 97.0 & $99.0 \mathrm{~b}$ \\
\hline Respiratory rate & 35.5 & 36.0 & 37.4 & 36.6 & $35.8 \mathrm{~b}$ \\
\hline Heart rate & 74.9 & 72.9 & 73.7 & 75.1 & $74.1 \mathrm{a}$ \\
\hline \multicolumn{6}{|c|}{ Afternoon } \\
\hline Rectal temperature & 38.9 & 39.0 & 38.9 & 39.0 & $39.1 \mathrm{a}$ \\
\hline Sweating rate & 145 & 139 & 118 & 129 & $135 \mathrm{a}$ \\
\hline Respiratory rate & 49.4 & 50.6 & 43.3 & 46.0 & $48.0 \mathrm{a}$ \\
\hline Heart rate & 77.9 & 73.5 & 73.9 & 77.1 & $75.8 \mathrm{a}$ \\
\hline
\end{tabular}

DM - dry matter.

Means followed by different lowercase letters differ statistically $(\mathrm{P}<0.05)$ from the same variables in different periods (morning $\times$ afternoon) by the Dunnett's test. 
In the erythrogram, it was observed that the Packed cell volume $(\mathrm{P}<0.05)$ increased with the inclusion of buriti oil in the diet of goats and a trend to increase it was observed for hemoglobin (Table 5). Total red blood cell count $(\mathrm{P}>0.05)$, mean corpuscular volume $(\mathrm{P}>0.05)$, mean corpuscular hemoglobin concentration $(\mathrm{P}>0.05)$, and total plasma protein $(\mathrm{P}>0.05)$ were not influenced by the inclusion of buriti oil in the diet. The hemoglobin concentration and red blood cells of lactating goats ranged from 9.8 to 10.4 $(\mathrm{g} / \mathrm{dL})$ and from 15.2 to $16.3\left(\times 10^{6} / \mu \mathrm{L}\right)$, respectively. The total leukocyte count $(\mathrm{P}>0.05)$ and differential count for neutrophils $(\mathrm{P}>0.05)$, eosinophils $(\mathrm{P}>0.05)$, lymphocytes $(\mathrm{P}>0.05)$, and monocytes $(\mathrm{P}>0.05)$ were not affected by the inclusion of buriti oil in the diet of goats.

\section{Discussion}

The lack of differences in the time spent in feeding, ruminating, and idling may be related to the similarity of particle size of the diet. This variable is used to evaluate the effectiveness of fiber use (Nicory et al., 2015). In addition, efficiency of DM intake and NDF were not influenced by addition of buriti oil in the diet of goats. The inclusion of buriti oil showed an average content of $\mathrm{NDF}_{\text {ap }}$ of $308 \pm 2 \mathrm{~g} \mathrm{~kg}^{-1}$ DM with minimal variation among treatments.

Some studies showed that some oilseed cakes had negative effects on the nutrient intake of DM, CP, and total digestible nutrients, which may result directly in the reduced milk production (Gonzaga Neto et al., 2015; Oliveira et al., 2015b). However, when we used oil in an amount that does not harm the ruminal microflora, there was a similarity in the intake of DM and DM digestibility, being different in the intake of NDF with reduction in goats subjected to 30 and $45 \mathrm{~g} \mathrm{~kg}^{-1}$ of buriti oil. There was no effect on time of ruminating chews (sec/bolus), in number of chews/bolus, and in the amount of chewed materials ( $\mathrm{g} / \mathrm{DM} / \mathrm{cake})$.

The use of oil in diets for ruminants has been related to low DM intake (Lana et al., 2007; Silva et al., 2007), which did not occur with the buriti oil at $45 \mathrm{~g} \mathrm{~kg}^{-1} \mathrm{DM}$ in the diet of goats. According to Jenkins (1993), vegetable oil supplementation in ruminant feed up to $60 \mathrm{~g} \mathrm{~kg}^{-1}$ can interfere in ruminal fermentation parameters and, consequently, lead to a reduction in the digestibility of nutrients, especially fiber, because of the physical effect on the feed particles by encapsulation, making it unavailable for bacterial adhesion (NRC, 2007). Furthermore, unsaturated fatty acids are toxic to cellulolytic bacteria and toxicity appears to be related to the increase in cell membrane fluidity, losing selective permeability and thereby reducing the ability to regulate intracellular pH and nutrient uptake (Jenkins, 1993).

Although the levels of total lipids varied from 3.41 to $7.54 \%$, in the diet with 0 and $45 \mathrm{~g} \mathrm{~kg}^{-1}$ of buriti oil levels, respectively, there was no interference in the rumination. Thus, the similarity between variables related to feeding behavior is the result of the similarity of physicochemical characteristics of dietary fiber with the addition of buriti oil in this study. That can be explained by the fact that replacing corn with oil, despite reaching $7 \%$ of the total diet, did not change the physical efficiency of the use of dietary fiber (Zhao et al., 2011). It was not necessary for the goats to change the feeding behavior to meet their physiology activities (urination, defecation, and water intake) and buriti oil levels did not harm the rumen microflora. However, rumination chewing efficiency can be reduced by diets with high fiber because of the greater difficulty to reduce the particle size of fibrous materials (Silva et al., 2015a,b).

Table 5 - Hematological parameters of crossbred lactating goats fed buriti oil levels

\begin{tabular}{|c|c|c|c|c|c|c|}
\hline \multirow{2}{*}{ Variable } & \multicolumn{4}{|c|}{ Buriti oil level $\left(\mathrm{g} \mathrm{kg}^{-1} \mathrm{DM}\right)$} & \multirow{2}{*}{ P-value } & \multirow{2}{*}{ Reference value } \\
\hline & 0 & 15 & 30 & 45 & & \\
\hline \multicolumn{7}{|c|}{ Erythrogram } \\
\hline Hemoglobin $(\mathrm{g} / \mathrm{dL})$ & 9.99 & 10.3 & 10.0 & 10.4 & 0.0661 & $6.00-13.0$ \\
\hline Erythrocyte $\left(\times 10^{6} / \mu \mathrm{L}\right)$ & 15.5 & 17.5 & 17.0 & 18.1 & 0.4022 & $8.60-20.0$ \\
\hline $\operatorname{MCV}\left(\mu \mathrm{m}^{3}\right)$ & 17.0 & 18.0 & 17.8 & 18.9 & 0.9712 & $10.0-28.0$ \\
\hline \multicolumn{7}{|c|}{ Leukogram } \\
\hline Leukocytes $\left(\times 10^{3} / \mu \mathrm{L}\right)$ & 12.7 & 13.6 & 12.7 & 14.2 & 0.5052 & $3.35-21.8$ \\
\hline Neutrophils $\left(/ \mathrm{mm}^{3}\right)$ & 8351 & 8584 & 8048 & 9419 & 0.1534 & $1200-7200$ \\
\hline Eosinophils $\left(/ \mathrm{mm}^{3}\right)$ & 188 & 229 & 172 & 228 & 0.1210 & $0.00-2997$ \\
\hline Lymphocytes $\left(/ \mathrm{mm}^{3}\right)$ & 3729 & 3918 & 4093 & 3765 & 0.9579 & $2278-13350$ \\
\hline Monocytes $\left(/ \mathrm{mm}^{3}\right)$ & 352 & 363 & 428 & 364 & 0.4293 & $0.00-6528$ \\
\hline
\end{tabular}

DM - dry matter; MCV - mean corpuscular volume; MCHC - mean corpuscular hemoglobin concentration; TPP - total plasma protein.

Means followed by different letters differ statistically $(\mathrm{P}<0.05)$ from the same variables in different buriti oil level by the Dunnett's test.

${ }^{1}$ Bezerra et al. (2008). 
The animals practically did not change their physiology with the inclusion of buriti oil in the diet. Thus, the lack of significant differences in the variables of rectal temperature and respiratory rate according to different levels of lipids in the diet probably occurred due to a little heat stress, especially in the morning (Table 2), combined with the fact that animals were not affected by direct solar radiation (Silva et al., 2006). However, there was a significant difference between periods of the day according to Silva et al. (2003) and Silva et al. (2006), who also reported a rise in the physiological variables in the afternoon due to higher thermal temperature. The efficiency of heat loss by conduction, convection, and radiation decreased due to the lower temperature gradient between the animal skin and the surrounding area. In that situation, the animal can maintain the normal body temperature by vasodilation, increasing peripheral blood flow and the surface temperature. However, the continuous rise in temperature demands the use of evaporation to keep homeothermy (Silva et al., 2016b).

Thus, ambient temperature increased $4{ }^{\circ} \mathrm{C}$ and relative humidity reduced $12 \%$ in the afternoon compared with the morning, which promoted an increase of 4.4 points on the black globe-temperature humidity index (BGTHI) and, consequently, increased the rate of physiological variables of goats in the afternoon. According to Souza et al. (2002), the figures of BGTHI up to 74 define a comfortable situation, 74-78 defines an alert situation, 79-84 defines a danger situation, and above 84 defines an emergency zone situation. Thus, the environmental variables observed in the morning indicated that the goats were under an alert situation and in the afternoon, under a dangerous situation. Thus, physiological parameters of goats were altered (thermoregulatory mechanism) in an attempt to minimize the effects of thermal discomfort. Silva et al. (2016c), in a survey conducted in the same region, observed that pregnant ewes changed their behavioral and physiological responses, mainly due to large daily variation of environmental parameters. According to the authors, these climate changes may result in a heat stress situation, with negative effects on the daily behavior of sheep causing losses in productive and reproductive performance of grazing animals.

Feed intake influences the endogenous heat production in ruminants, which varies much depending on the quantity and quality of the feed ingested. Thus, the thermal stress that usually occurs with animals raised in the Brazilian savanna region, due to the high temperature and low relative humidity, can reduce DM intake (Silva et al., 2016c) with decreased metabolic rate, in which the animals avoid eating and look for shadow, if available (Silva et al., 2015b; Silva et al., 2016b). In this sense, the use of oil in the diet can reduce the damage caused by heat, consequently increasing the energy density of the diet and little fermentation production of heat, resulting in reduction of body heat load (West, 1999). The present study confirmed this fact (heart rate and rectal temperature were similar among treatments). However, the body heat rises from the generation of heat inside the body via thermogenesis by oxidation of the nutrients of the feed and energy expended in the basal metabolism, growth, and physiological activity throughout the production.

The averages observed for RT, SW, RR, and HR were $38.7^{\circ} \mathrm{C}, 117.3 \mathrm{~g} / \mathrm{m} / \mathrm{min}, 41.9$ moviments $/ \mathrm{min}$, and 74.9 beats/min, respectively. These values were similar to results of other studies under similar environmental conditions (Silva et al., 2015a,b; Queiroz et al., 2015; Silva et al., 2016b), which indicate that the physiological parameters of animals were within of reference values for the studied species.

Rectal temperature was within the normal range for goats according to Baccari Junior et al. (1996), which assumes regular variation of 38.5 to $40^{\circ} \mathrm{C}$, being within the thermoneutral zone. However, it is known that heat stress is often transient and can only be seen in daily evaluation by physiological parameters (Silva et al., 2015a). That may explain the higher values for respiratory and sweat rate in the afternoon, which were influenced by higher ambient temperature during this period of the day. The respiratory rate may have increased as a strategy to lose heat in a short time (in the afternoon). However, if the rapid and continuous breath persists for long time, it can interfere on feeding and rumination behaviors, adding endogenous heat from muscle activity and divert energy that could be used in other metabolic and production processes. A decrease in voluntary feed intake is the first visible symptom presented by ruminants in response to heat stress (McDowell, 1974; Silva et al., 2016b). According to Silva and Starling (2003), evaporation capacity by skin has an important role in thermoregulation of ruminants under high-temperature environments, contributing with $63 \%$ of total evaporation.

The sweating maximum capacity is reached under high temperature and low humidity, when there is an increase in blood volume in the epidermis, which provides additional stimulus for the production of the sweat glands (Ligeiro et al., 2006). Thus, as the packed cell volume is an estimate of the mass of erythrocytes to the blood volume, which may increase due to the reduction of fluid, evaporative mechanisms for heat dissipation such as sweating can have increased hematocrit and MCV rate. This may have been even more intense in the afternoon because the sweating rate was greater, although there was no interference by 
diet. The sweating rate is a physiological mechanism which is used to dissipate heat by the sweat glands. It becomes more active when there is high ambient temperature and low relative humidity as occurred in this experiment (Aiura et al., 2010). In addition, the packed cell volume (27.0 to $29.0 \%$ ) remained within the reference values for goats in the same region (Bezerra et al., 2008). According to Bezerra et al. (2008), a long-term heat stress can reduce the number of red blood cells and packed cell volume, leading to hemoconcentration due to decreased intake of feed and water, directly affecting the absolute red blood cell count indices (MCV and $\mathrm{MCHC}$ ).

Changes in the leukocyte count number and differential counts in sheep and goats have been mentioned in the literature. There is a relative agreement of factors such as birth, pregnancy, surgical procedures, inflammatory processes, and parasitism affecting these cells. Nevertheless, some studies did not show influence of these factors on hematology of ruminants (Bezerra et al., 2008; Sousa et al., 2011). In this study, the inclusion of buriti oil did not change leukocyte count. The heat increment produced by the fiber digestion caused reduction on feed intake of Anglo Nubian lactating goats. Consequently, the goats were under negative energy balance, using their body reserves and presenting changes on hematological variables (Bezerra et al., 2013).

\section{Conclusions}

The inclusion of buriti oil is recommended in up to $45 \mathrm{~g} \mathrm{~kg}^{-1}$ (DM basis) as a replacement for ground corn in diet of lactating goat without affecting the feeding behavior and physiological and hematological variables. Period of the day influences the physiological responses of goats in the Brazilian savanna region, with significant use of heat dissipation mechanisms in the afternoon.

\section{References}

Aiura, A. L. O.; Aiura, F. S. and Silva, R. G. 2010. Respostas termorreguladoras de cabras Saanen e Pardo Alpina em ambiente tropical. Archives of Zootecnia 228:605-608.

AOAC - Association of Official Analytical Chemists. 1990. Official methods of analysis. 15th ed. Arlington, VA, USA.

AOAC - Association of Official Analytical Chemists. 2002. Official methods of analysis. 12th ed. Arlington, VA, USA.

Baccari Júnior, F.; Gayão, A. L. B. A. and Gottschalk, A. F. 1996. Metabolic rate and some physiological and production response of lactating Saanen goats during thermal stress. In: Proceedings of the14th International Congress of Biometeorology, Ljubjlana. 119p.

Berman, A. 1957. Influence of some factors on the relative evaporative rate from the skin of cattle. Nature 179:1256.
Bezerra, L. R.; Ferreira, A. F.; Camboim, E. K. A.; Justiniano, S. V.; Machado, P. C. R. and Gomes, B. B. 2008. Perfil hematológico de cabras clinicamente sadias criadas no Cariri paraibano. Ciência e Agrotecnologia 32:955-960.

Bezerra, L. R.; Torreão, J. N. C.; Marques, C. A. T.; Machado, L. P.; Araújo, M. J. and Veiga, A. M. S. 2013. Influência da suplementação concentrada e da categoria animal no hemograma de ovinos da raça Morada Nova. Arquivo Brasileiro de Medicina Veterinária e Zootecnia 65:1738-1744.

Buffington, D. E.; Collazo-Arocho, A.; Canton, G. H.; Pitt, D.; Thatcher, W. W. and Collier, R. J. 1981. Black-Globe-Humidity Index (BGHI) as comfort equations for dairy cows. Transactions of the ASAE 24:711-714.

Bürger, P. J.; Pereira, J. C.; Queiroz, A. C.; Silva, J. F. C.; Valadares Filho, S. C.; Cecon, P. R. and Casali, A. D. P. 2000. Ingestive behavior in Holstein calves fed diets with different concentrate levels. Revista Brasileira de Zootecnia 29:236-242.

Carvalho, G. G. P.; Pires, A. J. V.; Silva, F. F.; Veloso, C. M.; Silva, R. R.; Silva, H. G. O.; Bonomo, P. and Mendonça, S. S. 2004. Comportamento ingestivo de cabras leiteiras alimentadas com farelo de cacau ou torta de dendê. Pesquisa Agropecuária Brasileira 39:919-925.

Costa, J. B.; Oliveira, R. L.; Silva, T. M.; Ribeiro, R. D. X.; Silva, A. M.; Leão, A. G.; Bezerra, L. R. and Rocha, T. C. 2016. Intake, digestibility, nitrogen balance, performance, and carcass yield of lambs fed licuri cake. Journal of Animal Science 94:2973-2980. doi: $10.2527 /$ jas.2015-0143.

Durães, J. A.; Drummond, A. L.; Pimentel, T. A. P. F.; Murta, M. M.; Bicalho, F. S.; Moreira, S. G. C. and Sales, J. A. 2006. Absorption and photoluminescence of Buriti oil/polystyrene and Buriti oil/ poly (methyl methacrylate) blends. European Polymer Journal 42:3324-3332.

França, L. F.; Reber, G.; Meireles, M. A. A.; Machado, N. T. and Brunner, G. 1999. Supercritical extraction of carotenoids and lipids from buriti (Mauritia flexuosa), a fruit from the Amazon region. The Journal of Supercritical Fluids 14:247-256.

Gonzaga Neto, S.; Oliveira, R. L.; Lima, F. H.; Medeiros, A. N.; Bezerra, L. R.; Viégas, J.; Nascimento Jr, G. and Freitas Neto, M. D. 2015. Milk production, intake, digestion, blood parameters, and ingestive behavior of cows supplemented with by-products from the biodiesel industry. Tropical Animal Health and Production 47:191-200.

Jenkins, T. C. 1993. Lipid metabolism in the rumen. Journal of Dairy Science 76:3851-3863.

Johnson, T. R. and Combs, D. K. 1991. Effects of prepartum diet, inert rumen bulk, and dietary polythylene glicol on dry matter intake of lactating dairy cows. Journal of Dairy Science 74:933-944.

Lana, R. P.; Camardelli, M. M. L.; Rodrigues, M. T.; Eifert, E. C.; Oliveira, M. V. M.; Stradiotti Júnior, D. and Oliveira, J. S. 2007. Óleo de soja e própolis na alimentação de cabras leiteiras: consumo de matéria seca e de nutrientes e parâmetros de fermentação ruminal. Revista Brasileira de Zootecnia 36:191-197.

Licitra, G.; Hernandez, T. M. and Van Soest, P. J. 1996. Standardization of procedures for nitrogen fractionation of ruminant feeds. Animal Feed Science and Technology 57:347-358.

Ligeiro, E. C.; Maia, A. S. C.; Silva, R. G. and Loureiro, C. M. B. 2006. Perda de calor por evaporação cutânea associada às características morfológicas do pelame de cabras leiteiras criadas em ambiente tropical. Revista Brasileira de Zootecnia 35:544-549.

Lima, L. S.; Oliveira, R. L.; Garcez Neto, A. F.; Bagaldo, A. R.; Abreu, C. L.; Silva, T. M.; Carvalho. S. T. and Bezerra, L. R. 2015. Licury oil supplements for lactating cows on pasture. Canadian Journal of Animal Science 95:617-624.

McDowell, R. E. 1974. Bases biológicas de la producción animal em zonas tropicales. Acribia, Zaragoza. 
Mendes, F. B. L.; Silva, R. R.; Carvalho, G. G. P.; Silva, F. F.; Lins, T. O. J. D.; Silva, A. L. N.; Macedo, V.; Abreu Filho, G.; Souza, S. O. and Guimarães, J. O. 2015. Ingestive behavior of grazing steers fed increasing levels of concentrate supplementation with different crude protein contents. Tropical Animal Health and Production 47:423-428.

Mertens, D. R. 1997. Creating a system for meeting the fiber requirements of dairy cows. Journal of Dairy Science 80:1463-1481.

Nardone, A.; Ronchi, B.; Lacetera, N.; Ranieri, M. S. and Bernabucci, U. 2010. Effect of climate changes on animal production and sustainability of livestock systems. Livestock Science 130:57-69. doi: 10.1016/j.livsci.2010.02.011

NRC - National Research Council. 2007. Nutrient requirements of small ruminants: sheep, goats, cervids and New Words camelids. National Academy Press, Washington, DC.

Nicory, I. M. C.; Carvalho, G. G. P.; Ribeiro, O. L.; Silva, R. R.; Tosto, M. S. L.; Costa-Lopes, L. S.; Souza, F. N. C. and Nascimento, C. O. 2015. Ingestive behavior of lambs fed diets containing castor seed meal. Tropical Animal Health and Production 47:939-944. doi: 10.1007/s11250-015-0812-9

Oliveira, R. L.; Faria, M. M.; Silva, R.; Bezerra, L. R.; Carvalho, G. G. P.; Pinheiro, A.; Simionato, J. and Leão, A. G. 2015b. Fatty acid profile of milk and cheese from dairy cows supplemented a diet with palm kernel cake. Molecules 20:15434-15448.

Oliveira, R. L.; Palmieri, A. D.; Carvalho, S. T.; Leão, A. G.; Abreu, C. L.; Ribeiro, C. V. M.; Pereira, E. S.; Carvalho, G. G. P. and Bezerraa L. R. 2015a. Commercial cuts and chemical and sensory attributes of meat from crossbred Boer goats fed sunflower cake-based diets. Animal Science Journal 86:557-562.

Queiroz, E. O.; Macedo, F. A. F.; Barbosa, O. R.; Zancanela, V.; Mora, N. H. A. P. and Baliscei, M. A. 2015. Parâmetros fisiológicos e desempenho para ovelhas Santa Inês e cordeiros $1 / 2$ Dorper - Santa Inês nas estações verão e inverno. Revista Brasileira de Saúde e Produção Animal 16:199-209.

Schleger, A. V. and Turner, H. G. 1965. Sweating rates of cattle in the field and their reaction to diurnal and seasonal changes. Australia Journal of Agricultural Research 16:92-106.

Silva, G. A.; Souza, B. B.; Alfaro, C. E. P.; Azevedo Neto, J.; Azevedo, S. A.; Silva, E. M. N. and Silva, R. M. N. 2006. Influência da dieta com diferentes níveis de lipídeo e proteínas na resposta fisiológica e hematológica de reprodutores caprinos sob estresse térmico. Ciência e Agrotecnologia 30:154-161.

Silva, G. A.; Souza, B. B.; Silva, E. M. N.; Silva, A. K. B.; Costa, A. A. A.; Azevedo, S. A. and Azevedo Neto, J. 2003. Determinação de parâmetros fisiológicos e gradientes térmicos de caprinos no semi-árido paraibano. In: Anais do $2^{\circ}$ Simpósio Internacional sobre Caprinos e Ovinos de Corte. Governo do Estado da Paraíba, João Pessoa.

Silva, M. M. C.; Rodrigues, M. T.; Branco, R. H.; Rodrigues, C. A. F.; Sarmento, J. L. R.; Queiroz, A. C. and Silva, S. P. 2007. Suplementação de lipídios em dietas para cabras em lactação: consumo e efeciência de utilização de nutrientes. Revista Brasileira de Zootecnia 36:257-267.
Silva, R. G. and Starling, J. M. C. 2003. Evaporação cutânea e respiratória em ovinos sob altas temperaturas ambientes. Revista Brasileira de Zootecnia 32:1956-1961.

Silva, T. M.; Medeiros, A. N.; Oliveira, R. L.; Gonzaga Neto, S.; Queiroga, E.; Ribeiro, R. D. X. and Bezerra, L. R. 2016a. Carcass traits and meat quality of crossbred Boer goats fed peanut cake as a substitute for soybean meal. Journal of Animal Science 94:2992-3002. doi: 10.2527/jas.2016-0344.

Silva, T. M.; Oliveira, R. L.; Nascimento Junior, N. G.; Pellegrini, C. B.; Trajano, J. S.; Rocha. T. C.; Bezerra, L. R. and Borja, M. S. 2015a. Ingestive behavior and physiological parameters of goats fed diets containing peanut cake from biodiesel. Tropical Animal Health and Production 48:59-66.

Silva, T. P. D.; Bezerra. L. R. and Marques, C. A. T. 2016b. Ingestive behavior in small ruminants. LAP LAMBERT Academic Publishing, Saarbrücken. 76p.

Silva, T. P. D.; Marques, C. A. T.; Torreão, J. N. C.; Araújo, M. J. and Bezerra, L. R. 2015b. Intake, digestibility, milk yield and indicators of the metabolic status of native ewes fed supplemented diet under grazing system. Italian Journal of Animal Science 14:272-279.

Silva, T. P. D.; Marques, C. A. T.; Torreão, J. N. C.; Bezerra, L. R.; Araújo, M. J. and Lima, L. A. 2016c. Effect of concentrate supplementation and time scales of evaluation on behavioral and physiological responses of pregnant ewes on grazing system. Acta Scientiarum Animal Science 38:77-86.

Sousa, P. B.; Silva, E. F.; Monção, E. C.; Silva, M. J. M.; Silva, J. N. and Sousa, M. M. 2012. Caracterização físico-química, fenólicos totais e capacidade antioxidante in vitro de polpas de buriti (Mauritia flexuosa L.) desidratadas. Revista Cientec 4:75-83.

Sousa, R. S.; Sousa, I. K. F.; Paula, V. and Barrêto Júnior, R. A. 2011. Alterações hematológicas de ovinos submetidos à implantação de cânula ruminal e orquiectomia. Veterinária e Zootecnia $18: 485-487$.

Souza, C. F.; Tinôco, I. F. F.; Baêta, F. C.; Ferreira, W. P. M. and Silva, R. S. 2002. Avaliação de materiais alternativos para confecção de termômetro de globo. Ciência e Agrotecnologia 26:157-164.

Tempelman, R. J. 2004. Experimental design and statistical methods for classical and bioequivalence hypothesis testing with an application to dairy nutrition studies. Journal of Animal Science 82(E. Suppl.):E162-E172.

Van Soest, P. J.; Robertson, J. B. and Lewis, B. A. 1991. Methods for dietary fiber, neutral detergent fiber, and nonstarch polyssacharides in relation to animal nutrition. Journal of Dairy Science 74:3583-3597.

West, J. W. 1999. Nutritional strategies for managing the heat stressed dairy cow. Journal of Animal Science 77(Suppl. 2):21-35.

Yousef, M. K. 1985. Stress physiology in livestock. CRC Press, Boca Raton, FL.

Zhao, X. H.; Zhang, T.; Xu, M. and Yao, J.H. 2011. Effects of physically effective fiber on chewing activity, ruminal fermentation, and digestibility in goats. Journal of Animal Science 89:501-509. 